\title{
LITERATURA E HISTÓRIA: ENTRELACES DA RESISTENNCIA NAS OBRAS ÓRF T̃OS DO ELDORADO DE MILTON HATOUM E ILHA DA IRA DE JOÃO DE JESUS PAES LOUREIRO
}

\author{
Lourdes FERREIRA \\ Universidade Federal do Pará (UFPA) \\ flourdes8@gmail.com
}

Resumo: $O$ estudo busca tecer algumas reflexões, a respeito dos entrelaces percebidos entre literatura e história observados nas obras Órfãos do Eldorado de Milton Hatoum e Ilha da Ira de João de Jesus Paes Loureiro, determinantes para o trabalho da memória, em apontar a historicidade de uma sociedade e a sua maneira em lidar com situações limites da experiência humana. Para tanto, serão examinados os textos de Chartier (1990), bem como, da percepção de resistência vista por Adorno (1993), a emersão do imaginário, entendido por Paes Loureiro (2001), e o desenvolvimento a respeito da cultura amazônica.

Palavras-Chave: Literatura. História. Resistência.

\begin{abstract}
The study seeks to make some reflections about the perceived interweaving between literature and history observed in the works Orphans of Eldorado Milton Hatoum and Island of Wrath by John Jesus Paes Loureiro, determining the work of memory, in point the historicity of a society and its way of dealing with situations limits of human experience. For both, the texts of Chartier (2001) will be examined, as well as the perception of resistance seen by Adorno (1970), the emergence of the imaginary, understood by Paes Loureiro (2001), for the development regarding the Amazonian culture.
\end{abstract}

KEYWORDS: Literature. History. Resistance. 
Sabe-se que a literatura está ligada à demonstração do real, assumindo algumas funções que atuam diretamente no homem. Para Chartier (1990, p. 62-63), todo documento, seja ele literário ou não, é uma representação do real que se apreende, mas sem se desligar de sua realidade textual construída em regras próprias, advindas de um testemunho que cria "um real" na própria "historicidade de sua produção e na intencionalidade da sua escrita".

A partir dessa reflexão retoma-se que há tempos por meio de pesquisas e discussões acadêmicas tem-se percebido a presença efetiva de acontecimentos históricos no campo literário, levando em consideração que da obra literária emerge uma carga importante de formação cultural, política e social do sujeito. Vale ressaltar, que as associações observadas entre história e literatura favorecem ao homem perceber as transformações sociais vivenciadas pelo autor da obra, como um indivíduo inserido na sociedade, bem como na reflexão do ser humano enquanto um ser pleno de traumas, revoltas, abandonos e desamparos sejam psíquicos ou sociais.

Uma obra literária seja um romance, um livro de contos ou um poema contemporâneo, mais do que apresentar reflexões ao leitor, visa discursar sobre problemas e conflitos que estiveram presentes nas casas, lares e nações de milhares de pessoas. E que muitas vezes ou por alienação ou por subordinação às leis, ao conforto e a tantos poderes constituídos ao longo de séculos de violência, são deixados à parte pela sociedade.

Isso deve ser resolvido não apenas entre história e a literatura, mas pela evidencia proposta pelo autor de uma obra literária, em construir uma dinâmica discursiva de resistência em suas criações. A fim de mostrar pelas vozes de suas personagens a ausência de postura crítica do homem, o apagamento deste frente aos conflitos e o esquecimento do indivíduo em continuar resistindo aos tropeços e imposições de um sistema.

Sobre esse pensar, as ideologias, os discursos dominantes e de resistência tem sido tematizados pelos criadores literários em narrativas que trazem como "pano de fundo" as crenças populares a centenas de anos, presentes nas diferentes regiões brasileiras. No caso dos autores nascidos na região amazônica, suas obras apresentam peculiaridades regionais como o material lendário, o cenário de floresta, os tipos humanos, o rio, a urbanidade típica do lugar, demonstrando por meio de suas personagens não só as diferentes maneiras de 
justificar o mundo em que vivem, mas de continuar insistindo em não fazer parte da barbárie existente.

As obras Órfãos do Eldorado, de Milton Hatoum e A Ilha da Ira, de João de Jesus Paes Loureiro podem ser tomadas como narrativas amplas de manifestações social e histórica de uma época, sendo testemunho excepcional de experiências humanas, de hábitos, atitudes, sentimentos, inquietações, expectativas e resistência frente aos conflitos existentes.

A escritura desses autores registra múltiplos aspectos do complexo e conflituoso campo histórico e consequentemente social no qual se insere e sobre o qual se referem às obras. Elas são constituídas e constituintes a partir desse campo, bem como, testemunham um olhar, uma percepção da realidade, sendo elas instrumentos e proposições de caminhos, de valores, de regras, de atitudes e de formas de sentir.

O contexto social de cada uma das obras em estudo está condicionado a uma realidade histórica, refletida por meio dos discursos de cada personagem. Milton Hatoum em Órfãos do Eldorado traz a fase áurea e o declínio da borracha. Um ciclo intenso de exploração do látex, cuja fase de maior importância econômica estendeu-se do final do século XIX, até 1920. Após a Segunda Guerra, essa atividade novamente floresce, todavia com menor vigor. De acordo com Loureiro (2001, p. 81), “culturalmente esse período funcionou também no sentido de imposição de signos com repercussão fortemente ideologizante", reforçando o sentimento de inferioridade cultural do nativo, em face da cultura estrangeira.

Nesse raciocínio, o mesmo autor diz que o Ciclo da Borracha "representou a pressão urbana sobre o imaginário social das grandes cidades como Belém e Manaus, repercutindo, além disso, nas pequenas cidades e nas comunidades ribeirinhas" (LOUREIRO, 2001, p.81). Sobre esse período áureo na região GONDIM assinala:

A cidade modificava-se, ruas eram abertas, fábricas surgiam e mais pobres ficavam os operários. Os sonhos da casa própria foram substituídos pela realidade do desemprego depois que a fábrica atingira uma produção excepcional. A alta de 1919 foi seguida pela 
queda de 1920, ensaio do que iria acontecer em 1929. (1994, p. 255).

Em Ilha da Ira, João de Jesus Paes Loureiro intertextualiza com a história brasileira trazendo o levante da Cabanagem e a Ditadura brasileira, emergindo da sua obra a força e o poder. "Nesse sentido, a peça de Paes Loureiro dialoga igualmente com toda uma tradição ligada ao tema da ilha associada à violência de Estado" (SARMENTO-PANTOJA, 2011, p. 04).

O movimento Cabano foi uma revolta popular, ocorrida na província do Grão-Pará, no Brasil Império, entre os anos de 1835 e 1840. Os "revoltosos" eram moradores ribeirinhos da região Norte e moravam em cabanas em uma época na qual a miséria social extrema convivia com os cabanos (mestiços, negros libertos e índios destribalizados). Uma situação que provocou nessas etnias o sentimento de desamparo em relação ao governo da época, gerando sangrentas revoltas. Comerciantes e fazendeiros também manifestavam seu descontentamento com o governo regencial, pois queriam participar mais das decisões da província.

Foram cinco anos de violentos ataques entre os cabanos e o exército do governo. Em 1840, o governo regencial reprimiu definitivamente a revolta, contando com muitos cabanos presos e a grande maioria mortos. A Cabanagem foi uma das maiores revoltas da história brasileira.

Já ditadura brasileira teve início com o golpe militar de 31 de março de 1964, ao depor o então presidente João Goulart e empossando no cargo, o Marechal Castelo Branco. Período marcado na história brasileira por meio da implementação de Atos Institucionais (AI), vigorando a censura, perseguições políticas, supressão de direitos constitucionais e repressão àqueles que se manifestavam contrários ao regime instalado.

São décadas de agitação política no Brasil, período em que as principais capitais do norte do país (Belém e Manaus) retomavam o crescimento interrompido pela queda do preço da borracha. As indústrias viriam a despontar como uma nova perspectiva de progresso, precedidas pelo comércio de produtos como o cumaru, a piaçava e, 
principalmente, a juta. O crescimento desordenado inchava estas cidades, tomadas pelos caboclos abandonados pelo poder público e por aventureiros vindos de todas as partes do país, dando origem às primeiras invasões. A implantação de uma área de livre comércio, a Zona Franca de Manaus, foi mais uma preocupação militar no sentido de resguardar a região da cobiça estrangeira, do que realmente de integrá-la ao resto do país.

Em A Ordem do Discurso, Foucault (2004) analisa que interditar em nossa sociedade é um dos procedimentos de exclusão mais familiar. Quando não se interdita o sujeito fisicamente, barrando-o, faz-se por meio de silenciamento, seja este na fala, na censura, pois o indivíduo não possui o direito de dizer, nem de falar qualquer coisa em qualquer lugar, visto que os discursos sociais são selecionados como forma de conter as materialidades das falas as quais ameaçam a ordem vigente.

Segundo Adorno (1993) faz-se necessário entender a relação que é estabelecida entre o indivíduo e a dinâmica social, que objetiva a sua anulação. O autor diz que o individualismo que isola o ser humano, não favorece sua emancipação, apenas o faz um ser dócil e impotente, um exemplar da deformação social, por isso é preciso resistir.

As escrituras em pauta assinadas por Hatoum e Paes Loureiro causam no leitor uma espécie de vibração, como resultante de duas forças antagônicas, sendo elas a anulação e a resistência, que atravessam o discurso numa diagonal muito forte que fazem das suas práticas um espaço de polêmicas, onde os acontecimentos historiográficos são manifestados na narrativa.

Escrito em 2008, a novela Órfãos do Eldorado de Milton Hatoum, revela o comportamento e conflitos da humanidade, bem como, a busca incansável de conhecer a verdadeira felicidade. Com uma narrativa ligada à configuração de espaços que se entrelaçam ao subjetivismo da cultura amazônica, o autor reconstrói na obra, o Mito universal do Eldorado, que no século XVI, ativou a cobiça de muitos conquistadores e se definia como uma cidade pródiga em riquezas e justiça social, a qual se encontrava localizada nas terras do Novo Mundo (GONDIM, 1994). Para os personagens desta novela de Hatoum, o Eldorado seria um paraíso perdido submerso nas águas profundas do Rio Amazonas. 
A novela não apresenta capítulos, as frases da narrativa são curtas, não sendo apresentado no texto qualquer articulador de frases, explicando a forma da escritura contemporânea. É na construção de um discurso provocativo ao lendário amazônico, que o leitor terá habilidade de articular o entendimento da historia, percebendo-se também como interlocutor da narrativa, pois o protagonista apresenta pontos de observação para o leitor por meio da constante comunicação com o mesmo, por meio das imagens discursivas, possuindo duas funções no texto: a de narrador e a de personagem

A temporalidade da narrativa não é linear, configurada no discurso entre idas e vindas entre memória, devaneios e realidade de Arminto Cordovil. Este é apresentado no presente como velho, "louco" e pobre, do tempo de fartura restaram-lhe apenas lembranças. O relato das reminiscências a um viajante em busca de abrigo constitui a diegese da obra, parte de um mosaico que compõe a vida desta personagem. Cujo, ponto de partida e de chegada ao enredo são as ruínas e a ficção que se realizam a partir da tentativa de revelar o passado e de constantemente reconstituí-lo.

Um dos traços de resistência percebidos na personagem principal, Arminto Cordovil, se dá por meio de representações segundo o seu desejo do bem e do mal. Este narrador traz à tona a resistência do eu, frente aos valores ou antivalores do seu meio e transmite ao leitor uma subjetivação ética da ação de resistir.

Esse tratamento dado pelo autor às reflexões de Arminto permite que o leitor, acompanhe os movimentos não raro contraditórios de consciência, que trás aliada a um período social a sua própria decadência. O Eldorado sonhado e almejado por tantos naufraga levando consigo a riqueza de uma era, do seu redemoinho emergindo fome, pobreza, venda e compra de meninas para todos os tipos de subjugação bem como outros problemas sociais.

Nossa vida não se cansa de dar voltas. Eu não morava nesta tapera feia. O palácio branco dos Cordovil é que era uma casa de verdade.

Vi o cargueiro alemão uma única vez, de madrugada [...]. Sentei no cais flutuante e li a palavra branca pintada na proa: Eldorado. Quanta cobiça e ilusão 
O navio afunda e leva a empresa à bancarrota; mais um símbolo de solidão na vida de Arminto: "Mas a pior notícia chegou num telegrama do gerente da empresa: Naufrágio Eldorado no Pará. Venha para Manaus com urgência.

Ela perdeu a mãe, disse o barqueiro. E o pai ofereceu a filha para mim. (...) Senti o sangue esquentar. O sangue ruim dos Cordovil. Denísio não usava faca na cintura. Dei um tabefe no rosto do mentiroso. (HATOUM, 2008, p.14; 21; 53; 63).

Muitas vezes a ausência e o vazio de Arminto são preenchidos pela resistência do eu íntimo à imposição de uma sociedade e da sua própria identidade construída pelos princípios e instituições dirigidas pela ordem vigente. Embora ele partilhe dos mesmos valores e crenças, também se engaja na resistência aos antivalores, pois o narrador olha os seus problemas de modo peculiar; garantindo-lhe o exercício da fantasia e da memória.

Sobre essa reflexão Adorno (1993) assevera que mesmo em uma sociedade como à qual pertence Arminto, que vive em uma comunidade onde seus elementos lendários são a reposta para os infortúnios pessoais, os seus indivíduos adquirem em sua própria "personalidade", a forma de compreender profundamente a sociedade em que estão inseridos, pautada não na percepção coletiva, mas individual.

Desta maneira, Adorno (1993) procura revelar que o ser humano apresenta a estrutura social sobre o viés de uma organização subjetiva. Há uma individuação, que favorece uma subjetividade permeada pelos seus interesses e valores que acredita e que insiste em lutar por eles.

A obra A Ilha da Ira é uma peça de teatro produzida pelo paraense João de Jesus Paes Loureiro e narra a história de uma ilha governada pela misteriosa personagem "Velha" que subjuga seus náufragos, valendo-se da violência física e psicológica. A Ilha é um lugar em que torturas e assassinatos possuem presença permanente e estão sempre interligados à malvada personagem.

Uma das proibições naquele lugar é o amor-carnal, que acarreta aos náufragos severo castigo, pago com a morte pela transgressão. Os náufragos que se dialogam entre si ao longo da narrativa, eram atores de uma companhia de teatro, que se encontravam em 
viagem, quando seu navio Adamastor veio a naufragar sendo eles e seus despojos, resgatados por outros náufragos àquela ilha perdida.

Todos naquele lugar vivem subjugados ao controle da Velha. Medo, terror e violência extrema fazem parte do cotidiano da Ilha. $\mathrm{O}$ medo nasce da violência física e psíquica, percebendo-se a aniquilação de qualquer resistência mediante o poder daquela personagem. Segundo Tânia Sarmento-Pantoja (2009), a maléfica Velha, "reúne ao mesmo tempo os códigos do grande ditador e do grande espoliador, representando o que há de mais sombrio no ser humano" (SARMENTO-PANTOJA, 2009, p. 05).

O estado de suspense e alerta resultante das ameaças são percebidos na atmosfera da Ilha, possuindo os náufragos viventes na ilha uma função: de trazer outros prisioneiros para ficarem sob o domínio da Velha, por acreditarem que os mantimentos e outros objetos que chegam do mar suprem as suas necessidades. Isso é observado na primeira cena, quando os moradores da ilha, em coro, suplicam na beira da praia pedindo a vinda de mais náufragos:

$1^{\circ}$ Senhora dos desesperados, valei-nos.

$2^{\circ}$ Valei-nos, Senhora.

$3^{\circ}$ Senhora dos desesperados,

$4^{\circ}$ Mãe de Deus,

$5^{\circ}$ Agora e em todas as horas,

$6^{\circ}$ Valei-nos Senhora.

$7^{\circ}$ Nossa miséria é grande

$8^{\circ}$ e a vida é pequena, Senhora.

$9^{\circ}$ Nossa vila é sem fartura,

(...)

$14^{\circ} \mathrm{A}$ vida que é nossa morte.

$15^{\circ} \mathrm{A}$ morte que é nossa sorte

$17^{\circ}$ Agitai o mar com vossa saia

$18^{\circ}$ que a barra da onda traz

$19^{\circ}$ fartura à praia, Senhora

$25^{\circ}$ Nós estamos sós,

$26^{\circ}$ Nós estamos nus.

$27^{\circ}$ Nós estamos fome (LOUREIRO, 2001, p.149)

Um ponto a ser observado além das atrocidades físicas e psicológicas realizadas pela Velha, o esquecimento é um importante sinalizador da dominação. Ele nasce dos sentimentos de desesperança, abandono e desamparo, fazendo com que aos poucos os 
habitante tornem-se apáticos e esqueçam como chegaram ali e até mesmo, a suas próprias identidades.

Diálogos intertextuais com narrativas mítico-lendárias amazônicas e clássicas estão presentes na obra. Além da Velha que se aproxima em demasia com o mito da Matinta Perera, o material narrativo apresenta discursos de personagens como o Caapora e o Curupira. O personagem do gigante Adamastor de Camões encontra-se resgatado na denominação do navio dos atores, bem como, outro mito clássico é reconfigurado no enigmático personagem Ulisseu, o único militante em A Ilha da Ira, que tenta em vão dar cabo a ditadura da Velha.

Na Ilha comandada pela "Velha" não há esperança, não há como reverter o seu poder absoluto, tão grande que no final os náufragos são encerrados numa réplica do navio "Brigue Palhaço" passam fome e sede quando a morte vem, após desesperos e alucinações.

Todos os náufragos se tornam dóceis ao poder da Velha, exceto Ulisseu. O traço de resistência encontra-se nesse personagem. Ele aparece junto aos náufragos, no entanto, ninguém sabe como ele chegou à ilha e ao final da peça, como ele desaparece, mas é um militante que tenta dar fim ao poderio da terrível feiticeira.

Alguns discursos de Ulisseu faz-se pertinente destacar, como:

Eu ainda acho que poderemos conseguir alguma coisa.

(...)

E o que eu faço para desencantar essa terra, o que eu faço?

\section{(...)}

Eu sei. Mas sei que também não quero matar-me aqui. Eu e meus companheiros. Haveremos de encontrar uma saída.

(...)

nossa tarefa é realmente arriscada.

\section{(...)}

Se me calo não é que deseje ser herói, mas fico enfurecido de verme acorrentado, como vocês, no castigo deste porão imundo.

(LOUREIRO, 2001, pp 161; 163; 164; 174; 188).

A resistência e a insistência de Ulisseu em deter a Velha é uma tentativa importante na obra, gerando atitudes dos náufragos em prol de uma transformação. De acordo com Adorno (1993), da mesma maneira que a insistência denuncia a anulação dos indivíduos, 
revela a repulsa em relação a toda e qualquer estratégia de fazer do homem o bode expiatório da barbárie implantada. Apesar da situação de anulação, de subjugação imposta por uma sociedade totalitária, o autor insiste que mesmo assim, o sujeito resista. E é sobre essa reflexão que o personagem Ulisseu se apresenta na narrativa.

Os náufragos que são atores em A Ilha da Ira enfocam por meio de seus discursos mecanismos advindos de subsídios culturais, para dar respostas a não ir de encontro ao poder da Velha. A intencionalidade de personagens como Patroni, Heitor e até mesmo o Caapora revela ao leitor, a dimensão estética da obra. A questão da intertextualidade com o material lendário amazônico e clássico, aliado ao contexto histórico que a obra retrata, rememora aspectos diversos de recepção, a qual pode ser pensada como uma forma de produção de sentidos.

O personagem Ulisseu de A Ilha da Ira procura, por meio de suas ações e discursos, revelar que se hoje os últimos traços de humanidade parecem desprender-se dos indivíduos, possuindo estes, ações injustas contra outros seres humanos faz-se necessário rememorar Adorno (1993) e não somente insistir, mas resistir e, pôr um fim as atrocidades que individualizam os homens para que estes sintam o seu poder dissipado e se vejam mergulhados em seu próprio isolamento.

\section{Considerações Finais}

Recorrer a um contexto social já vivenciado e registrado na História para ser abordado em uma obra literária, possibilita o acesso ao imaginário social do leitor, emergindo um conjunto de imagens acerca da existência humana em sociedade, às formas de agir, o comportamento, o ato pensar e sonhar, de sentir e relacionar-se. Tendências peculiares de um tempo, de um lugar e de uma época social.

As obras refletidas neste estudo trazem para o leitor as representações de um mundo social, de uma realidade, tanto objetiva quanto subjetiva, de um tempo e lugar, resultando no entrecruzamento de aspectos individuais e coletivos de uma região brasileira. Elas revelam o que Candido (1985, p. 24) assevera ao dizer que criatividade, a imaginação e a 
originalidade, partem das condições reais do tempo e do lugar, as quais, ressaltamos, podem ser concretas ou não, da existência social e de suas experiências.

João de Jesus Paes Loureiro e Milton Hatoum ressaltam em suas obras que a experiência de suas personagens e o seu testemunho nasce com das potências do conhecimento, da imaginação, da memória. A vivência de fatos sofridos é sempre uma fonte documental, veiculadora e articuladora de representações produzidas por quem narra seu sofrimento, assim como, para o receptor dessa narrativa.

Órfãos do Eldorado, de Milton Hatoum e A Ilha da Ira de Paes Loureiro são uma representação de fontes históricas e de práticas sociais, trabalhadas com objetivo de serem um dispositivo, no qual se descortina o passado vivido, suas inquietações, conflitos, explorando forças catalizadora do viver em sociedade, como os seus valores, amores, medo, desamparo, violência, associando-as a elementos lendários e crenças da cultura amazônica.

E é nas ligações entre bem e mal, inocência e culpa, resistência e acomodação, vontade e destino que reside à pressão ideológica, revelando por meio da exigência estética, uma genuína face ética.

\section{Referências:}

ADORNO, T. W.. Minima moralia. Reflexões a partir da vida danificada. São Paulo: Ática. 1993.

CANDIDO, Antonio. Literatura e sociedade: estudos de teoria e história literária. São Paulo: Nacional, 1985.

CHARTIER, Roger. A história cultural: entre práticas e representações. Lisboa: Difel,1990.

FOUCAULT, Michel. A Ordem do Discurso. São Paulo: Loyola, 2004.

GONDIM, Neide. A Invenção da Amazônia. São Paulo: Marco Zero, 1994.

HATOUM, Milton. Órfãos do Eldorado. São Paulo: Companhia das Letras, 2008.

MARGENS - Revista Interdisciplinar

Versão Digital - ISSN: 1982-5374
Dossiê: Literatura e Resistência

VOL.9. N. 13. Dez 2015. (p. 155 - 166) 
PAES LOUREIRO, João de Jesus. A Ilha da Ira. In: Obras Reunidas: teatros e ensaios. Vol.3. São Paulo: Escrituras, 2001.

SARMENTO-PANTOJA, Tânia. Platôs da ilha utópica em território amazônida: Benedicto Monteiro e João de Jesus Paes Loureiro. In: RODRIGUES, Rauer Ribeiro; GRACIARODRIGUES, Kelcilene, BELON, Antônio Rodrigues (orgs). O Local e o Regional. Literatura em Perspectiva. Campo Grande: Editora da Universidade Federal do Mato Grosso do Sul, 2009.

. Literatura e História: intermediações sobre a Amazônia em Benedicto Monteiro e João de Jesus Paes Loureiro. XII Congresso Internacional da ABRALIC. Curitiba: UFPR, 2011. 